\title{
Problem Genişletme Etkinliklerinin Problem Çözme Başarısına ve Üstbilişe Etkisi
}

\author{
Seyfi ALAN \\ Dr. M. Hilmi Güler Bilim ve Sanat Merkezi, Ordu \\ seyfialan52@gmail.com \\ ORCID ID: https://orcid.org/0000-0001-7313-6572 \\ Gökhan ÖZSOY \\ Ordu Üniversitesi, Eğitim Fakültesi, Temel Eğitim Bölümü, Ordu \\ gozsoy@odu.edu.tr \\ ORCID ID: https://orcid.org/0000-0002-1250-624X
}

Araştırma Makalesi

Geliş Tarihi: 09.08.2019
Revize Tarihi: 26.11.2019

DOI: $10.31592 /$ aeusbed.604524

Kabul Tarihi: 27.11 .2019

\section{Atıf Bilgisi}

Alan, S. ve Özsoy, G. (2019). Problem genişletme etkinliklerinin problem çözme başarısına ve üstbilişe etkisi. Ahi Evran Üniversitesi Sosyal Bilimler Enstitüsü Dergisi, 5(2), 439-458.

\section{ÖZ}

$\mathrm{Bu}$ çalışmanın amacı, problem genişletme etkinliklerinin öğrencilerin problem çözme başarısına ve üstbiliş becerisine etkisinin incelenmesidir. Bu doğrultuda araştırma, ön test-son test kontrol gruplu deneysel desen üzerine modellenmiştir. Araştırma, 2015-2016 eğitim öğretim yılının ikinci döneminde Rize İli Merkez İlçesi'nde bir ilkokulda, 31'i deney ve 30'u kontrol grubunda olmak üzere, toplam 61 öğrenci ile dokuz hafta boyunca yürütülmüştür. Araştırmada, deney grubunda yer alan öğrencilere problem genişletme etkinlikleri uygulaması yapılırken, kontrol grubunda yer alan öğrencilerin öğrenme sürecine herhangi bir müdahale yapılmamıştır. Araştırmada kullanılan veriler; problem çözme başarı testi ile üstbilişsel bilgi ve beceri ölçeği kullanılarak elde edilmiştir. Araştırma sonucunda, deney grubundaki öğrencilerin uygulama süreci sonunda hem problem çözme başarısında hem de üstbilişsel bilgi ve beceri düzeylerinde artış olduğu görülmüştür. Ayrıca bu artışın deney grubunda, kontrol grubuna oranla daha yüksek olduğu gözlenmiştir. Bunun yanında hem kontrol hem deney test ve son-testte problem çözme başarı testi ile üstbiliş bilgi ve beceri ölçeğinin yüksek düzeyde korelasyona sahip olduğu görülmüştür. Elde edilen sonuçlara göre, problem genişletme etkinliklerinin hem problem çözme başarısında hem de üstbiliş bilgi ve becerilerinde artış sağladığı belirlenmiştir.

Anahtar Kelimeler: İlkokul matematik öğretimi, problem çözme, problem genişletme, problem çözme başarısı, üstbiliş.

\section{Effect of Problem Extending Activities on Problem Solving and Metacognition}

\begin{abstract}
The aim of this study is to investigate the effect of problem extending activities on students' problem-solving achievement and metacognition skills. Accordingly, the research was modeled on experimental design with pre-test and post-test control groups. The research was carried out for nine weeks in a primary school in the central district of Rize province with a total of 61 students in 31 experimental and 30 control groups in the second semester of 2015-2016 academic year. In the study, while the problem extending activities were applied to the students in the experimental group, no intervention was made to the learning process of the students in the control group. The data used in the research; problem solving achievement test and metacognitive knowledge and skills inventory. As a result of the research, it was seen that both the problemsolving achievement and metacognitive knowledge and skill levels increased in the experimental group at the end of the application process. In addition, this increase was higher in the experimental group compared to the control group. In addition, it was observed that there was a high correlation between metacognitive knowledge and skills inventory and problem-solving achievement test in both control and experimental test and post-test. According to the results, it was determined that problem-extending activities increased both problem-solving achievement and metacognitive knowledge and skills.

Keywords: Elementary school mathematics teaching, problem solving, problem extending, problem solving achievement, metacognition.
\end{abstract}

\section{Giriş}

Problem, insan zihnini karıştıran, ona karşı meydan okuyan ve inancı belirsizleştiren her şey olarak tanımlanmaktadır (Baykul, 2000). Schoenfeld (1992), problemi iki şekilde; "Matematikte herhangi bir şeyin yapılması gerektiği durum" ve "Kafa karıştırıcı veya zor olan bir soru" olarak 
tanımlamaktadır. Tanımlara göre problem, hem matematik kitaplarında yer alan hesap işlemleri yapmak kadar basit olabilir hem de bir grup matematikçinin çözüme ulaşmak için uzun zaman beraber çalışması gerektiği kadar da karmaşık ve güç olabilir (Karataş, 2008). Piaget'in (1976) de açıkladığ1 gibi, bireyin bilişsel dengesi yeni bir durumla karşılaş̧nca ve herhangi bir nesneye zihninde mevcut bilgileri ile anlam veremediği zaman bozulur. Bu duruma bilişsel ikilem veya karmaşa da denilebilir. Çoğu zaman yeni durumla, bireyin var olan bilgileri örtüşmüyorsa zihinsel denge bozulur ya da birey doğal olarak karmaşayı çözme durumunda kalır. Böylelikle bu durum birey için bir problem halini alır (Baki ve Bell, 1997).

Çocukların günlük hayatlarında karşılaştıkları problemleri çözmelerinde, diğer disiplinlerde başarılı olabilmeleri ve üst düzey düşünme becerilerin geliştirmelerinde matematik önemli bir araçtır (Temur ve Kılınç, 2016). Matematik öğretimi ve öğrenimi üzerine çoğu yetkili kurum (National Council of Teachers of Mathematics [NCTM], 2000; National Mathematics Advisory Panel [NMAP], 2008) problem çözmeyi matematik eğitiminin odak noktası yapmayı savunmaktadır. Matematik alanındaki artmakta olan araştırmalar ve eğilimler, matematik araştırmaları ve uygulaması üzerinde bu tezin etkisini yansıtmaktadır (Bruning, Schraw ve Norby, 2014). Problem çözme araştırmalarının en genel amacı, yeni bir problemle karşılaştığımızda yapılacaklara karar verme durumunda kullandığımız stratejileri belirlemek, sorunu temsil etmenin bir yolunu bulmak ve amacımıza ulaşmayı mümkün hale getirecek bir eylem seçmektir (Smith ve Kosslyn, 2014). Matematik öğretmenin en önemli amaçlarından birisi, öğrencilerimizin iyi bir problem çözücü olmalarını desteklemektir. Matematik dersi öğrencilere problem çözme becerisini kazandırmak isterken temel amaç, onları ileride karşılaşabilecekleri günlük hayat problemlerinin çözümüne hazırlamaktır (Özsoy ve Ataman, 2009). Ayrıca problem çözmek sadece matematik öğrenmenin bir amacı değil, aynı zamanda onun temel aracidir.

Problem çözme konusunda yapılan araştırmalar öğrencilerin arzu edilen başarı düzeyine ulaşamadıklarını göstermektedir (Özsoy, 2005; Polya, 1988; Schoenfeld, 1985; Tertemiz ve Çakmak, 2003). Bununla birlikte Trends in International Mathematics and Science Study [TIMSS] 2015 ön raporuna göre, 4. sınıf düzeyinde, Türkiye 483 puan ile matematik başarı ortalaması olarak 49 ülke arasında 36. sırada yer almıştır. Ayrıca dördüncü sınıf matematik sonuçları Türkiye'nin TIMSS puanının 2011 sonucuna göre 14 puan arttığını göstermektedir (Polat, Gönen, Parlak, Yıldırım ve Özgürlük, 2016). Bunun yanında Programme for International Student Assessment [PISA] 2015 raporuna göre matematik okuryazarlı̆g 1 alanında katılan tüm ülkelerin ortalaması 461 iken, Türkiye ortalaması 420'dir (Taş, Arıcı, Ozarkan, ve Özgürlük, 2016). PISA sınavlarındaki matematik okuryazarlığ 1 alanındaki ortalama puanlar sınav yıllarına göre incelendiğinde Türkiye'deki öğrencilerin PISA 2015 performansının PISA 2009 ve PISA 2012'ye göre daha düşük seviyede olduğu görülmektedir. PISA ve TIMSS 2015 sonuçlarına göre matematikte en fazla temel işlem/basit problem çözebilen ve bu düzeyin altında olan öğrencilerimizin oran $\% 76$ ve daha kötüsü matematikte "gerçekleştirdikleri akıl yürütmelerini anlatabilenler" ise \%1'dir. İnsanoğlunun en önemli ve farkl1 becerisi olan problem çözme ve akıl yürütme kısmında bu kadar zayıf olmamız her alanda gelişmemizi engelleyen en önemli eksikliklerimizden biridir (Karabey, 2017).

Haylock ve Cockburn'a (2014) göre herhangi birinin matematikte problem çözmeyi başaramamasının genel nedeni, düşüncelerini bir yerde kısıtlamasıdır. Tüm olası sonuçları düşünmezler, probleme nasıl yaklaşacaklarına dair genellikle tek bir fikirleri vardır, takıldıklarında başka yaklaşımları düşünmeyi başaramazlar. Gelişmiş problem çözme becerileri için, alışılmışın dışında bir yaklaşıma ihtiyaç olduğu açıktır. Bu ihtiyaçtan hareketle bu araştırmanın temel amacı problem çözme ve üst düzey düşünme becerilerinin geliştirilmesine katkı sağlayacak yaklaşımları denemektir. Bir problem çözülüp kontrol edildikten sonra, hemen ardından buna benzer yeni bir probleme geçmek yerine hâlihazırda çözülen problemin genişletilmesinin çok daha faydalı olacağı düşünülmüştür. Problemin genişletilmesine yönelik bu etkinlikler, problem çözme başarısında en önemli faktörlerden birisi olan tecrübe gelişimine, strateji birikimine ve bu birikimin sonraki durumlara transfer edilmesini sağlayacaktır. Bu yöntemin problem çözme ve üst düzey bilişsel beceriler bakımından önemli katkılar getireceği öngörülebilir. 
Problem çözme becerisi, belki de insanoğlunun neslinin varlığını devam ettirebilmesi için gerekli en temel yetenektir. İnsanın toplum hayatında ne zaman ne tür zorluklarla karşılaşacağı veya nasıl ihtiyaçlarının oluşacağı bilinemez. Bunun için çağdaş eğitim kendi kendine zorlukların üstesinden gelebilen kişiler yetiştirmeyi hedeflemektedir. Bundan dolayı problem çözme ve dolayısıyla problem çözme öğretimi çok önemlidir. Matematik problemi kişinin kolaylıkla çözüme ulaşması için gerekli stratejiye sahip olmadığı, çözmek için çaba göstermesi gerektiği ve çözüm bulma isteği uyandıran ya da ihtiyacı hissettiren bir görevdir (Lester, 1983).

George Polya (1981) matematiksel problem çözmenin dört adımını göstermiştir. Bu adımlar birçok ders kitabında ve kaynak kitabında yer yer almaya devam etmektedir. Bu adımların bilinmesi problem çözme becerilerini geliştirebilir; çünkü ne istendiğinin bilinmesi, hangi yöntemin seçileceği gibi tercihler, çözen kişinin seçimine bağlıdır. Bu dört aşama: Problemi anlama, Çözüm için plan hazırlama, Planı uygulama ve Çözümü değerlendirme şeklindedir.

Problemi anlama: Kısaca problemin ne ile ilgili olduğunu anlamaktır. Öğrenci bu aşamada problemi kendine göre anlamlandırmaya çalışır. Problemle ne anladıklarını öğrenciler kendi ifadeleriyle, kendi kelime, şekil ve sembolleri ile yeniden açıklarlar. Öğrenciler problem çözme etkinliğini grup çalışması olarak gerçekleştiriyorlar ise onlar bu aşamada problemi başkasının anlayacağı şekilde yeniden ifade edip, yazıp, çizip veya anlatmalıdırlar. Problemi ifade eden tablo, grafik, şekil oluşturmaya çalışır. Problemdeki verileri düzenler ve eksik veya fazla bilgileri belirlemeye çalışır. Çözüm için kullanacağı bilgileri düzenler.

Çözüm için plan hazırlama aşaması: Bu aşamada öğrenci problemi nasıl çözeceğini düşünür ve problemde verilenleri ve istenenleri belirlemeye çalışır, süreci planlar. Bu belirlemeden sonra verilenleri kullanarak nasıl çözüme gidilebileceğini araştırır. Bu süreçte şekil, tablo, grafik ve denklemlerden yararlanır. Ayrıca planlama yeteneği, iyi problem çözücü ve kötü problem çözücü arasındaki faklardan biridir. $\mathrm{Bu}$ yetenek beceriye, ön bilgilere ve problem çözme stratejilerinden haberdar olmasına dayalı olan becerilerdir. İyi problem çözücüler ileriye yönelik planlama yaparlar ve problem çözme sırasını ve önceliğini daha etkili bir şekilde koordine ederler (Bruning vd., 2014).

Planı uygulama aşaması: Problem çözümü için kullanılacaklar arasında tablolar var ise onlar oluşturulur. Grafikler kullanılacaksa verilerden ve formüllerden yaralanarak grafikler çizilir. Bunlardan yararlanılarak çözüm için deneysel gözlemler, doğrulamalar veya genellemeler yapılmaya çalışılır veya formüller kullanılır. Kurulan denklemler çözülerek problemin çözümüne ulaşılmaya çalış1ıı. Kısacası problem çözümünde tabloların, grafiklerin, seçilen formüllerin ve stratejilerin denklemlerin çözüme katkı sağlayıp sağlamadığına bakılır.

Değerlendirme aşaması: Bu aşama öğrenciler tarafindan, belki de en önemli fakat en çok ihmal edilen aşamadır. Bu aşamada öğrenci problem çözümü boyunca yaptıkları üzerinde düşünür. Geriye dönerek çözüm için hazırlanan planını ve çözüm yolunu değerlendirir. Çözüm yolu sonuca ulaştırmışsa başka çözüm yollarının olup olmadığına veya problemin koşulları değiştiğinde aynı çözüm yolunun kullanılıp kullanılamayacağına bakar. Eğer hazırlanan plan veya çözüm yolu sonuca ulaştırmamışsa öğrenci başa döner problemi doğru anlayıp anlamadığına bakar ve planında gerekli düzenlemeleri yaparak yeniden çözüme ulaşmaya çalışır (Polya, 1981). Herhangi bir kimse "çözümleri değerlendirmek önemsizdir" diye düşünebilir, çünkü normalde değerlendirme problem çözüldükten sonra yapılır. Fakat işin aslı böyle değildir. Problem çözme sürecini ve ürününü değerlendirmekte başarısız olan kişiler bu becerileri geliştirmek için mükemmel bir firsatı kaçırırlar (Bruning vd., 2014). Ayrıca Polya'ya (1981) göre problemin çözümünü kontrol etme aşamasında şu adımlar izlenmeli ve sorulara yer verilmelidir:

- Elde edilen çözümü inceleyin. Çözümü kontrol edebilir misiniz?

- Farklı bir çözüm elde edebilir misiniz? Bunu bir bakışta görebilir misiniz?

- Sonucu ya da stratejiyi başka bir problem için kullanabilir misiniz? 


\section{Problem Genișletme}

Problem genişletme, alan yazında bu başlıkla ayrı bir kavram olarak ele alınmamakla ve ayrıntılı biçimde tanımlanmamakla birlikte, bazı çalışmalarda (Contreras, 2007; Schoenfeld, 2014; Turhan, 2011; Van de Walle, Karp, Lovin ve Bay-Williams, 2010) 'problem çözme ve problem kurma' başlikları altında değişik şekillerde önerildiği görülmektedir. Problem genişletme çalışmalarında, problem çözüldükten sonra yeni bir probleme geçilmeden, sistemli ve düzenli bir şekilde çözülen probleme farklı sorular eklenip, ana problem genişletilerek probleme ve problem çözmeye farklı ve daha etkili bir boyut kazandırılabilir. Bu yolla çözülen problemdeki yöntem, strateji ve birikim, karşılaşılabilecek yeni durumlara transfer edilebilir ve böylece problem çözme becerisinin gelişimine daha yüksek düzeyde bir katkı sağlanabilir. Bununla birlikte Contreras'ın (2007) çalışmasında, temel problemin matematiksel bir özelliğinin, özgün bir matematiksel özelliğe ait özel bir durumla değiştirilerek özel problemler oluş̧urulabileceğinden bahsedilmiştir. Temel probleme ait matematiksel bir özellik ile benzer bir özellik yer değiştirilerek genişletilmiş problemler üretilebilir. Van de Walle ve arkadaşları (2007) problem çözmede 'Değerli genişletmelere zemin oluşturunuz' şeklinde ifade kullanmaktadır. Burada problemi sınıf düzeyinden önce bitiren öğrencilere, “... olsa ne olurdu?" ya da "Bu fikir sence bu durum için de uygulanabilir mi" gibi sorularla öğrencilerin düşünmelerini onları motive ederek devam ettirmelerini sağlamak önerilmektedir (Van de Walle vd., 2010). $\mathrm{Bu}$ araştırmada ise çeşitli araştırmacılar tarafından (Contreras, 2007; Schoenfeld, 2014; Van de Walle vd., 2010) önerilen yaklaşımlar sistematik hale getirilerek "problem genişletme" adıyla problem çözme sürecinin ve problem çözme çalışmalarının bir parçası olarak tanımlanması uygun görülmüştür.

Problem genişletme etkinlikleri, problem çözme başarısı sağlamada en önemli öğelerden birisi olan tecrübe gelişimine, strateji birikimine ve bu birikimin sonraki problem durumlarına transfer edilmesini sağlamaya önemli katkılar getirecektir. Ayrıca problem genişletme çalışmaları, matematiksel problem kurma becerilerinin gelişiminde de faydalı olacaktır (Millî Eğitim Bakanlığı [MEB], 2015). Problem genişletme üzerine örnekler literatürde ve matematik kitaplarında hâlihazırda yoktur. Problem genişletme örnekleri üzerine çalışmalar yapılarak matematik öğretiminde kullanılmaları sağlanabilir.

Polya (1988), problemin çözüm ve değerlendirme aşamasından sonra öğrencilerdeki yaratıcı ve eleştirel düşüncenin gelişimine katkı sağlamak için ek aktivitelerin yapılabileceğini belirtmiştir. Örneğin; öğrencilerden problemi farklı yollardan çözmeleri, eldeki probleme benzer yeni problem üretmeleri, problemin çözümünde kullandıkları yöntem ve stratejileri önceden problem çözerken kullanmış oldukları yöntem ve stratejilerle mukayese edebileceklerini belirtmiştir.

Contreras'a göre (2007) Verilen bir problemden yeni matematik problemleri üretmede, ispat etme, tersine çevirme, ayrıntılara girme, genelleştirme ve genişletme olmak üzere birbirini izleyen matematiksel süreçler uygulanarak, bazı problemler değiştirilip yeni problemler üretilebilir. $\mathrm{Bu}$ süreçleri uygulayarak, ispat problemleri, karşıt problemler, özel problemler, genel problemler ve genişletilmiş problemler olmak üzere birbirini izleyen problemler üretilebilir. Ana problemde, bilinen bir özellik bilinmeyen bir özellik ile değiştirilerek ve tersine çevrilerek karşıt problemler üretilebilir. Temel problemin matematiksel bir özelliğini, özgün bir matematiksel özelliğe ait özel bir durumla değiştirilerek özel problemler üretilebilir. Temel probleme ait matematiksel bir özellik ile benzer bir özellik yer değiştirilerek genişletilmiş problemler üretilebilir (Turhan, 2011). Öğrenciler farkl1 problem türlerini tanımaya ve hem problem türleri arasında ayrım hem de matematiksel bilgi birikimlerinin daha iyi bir genellemesine götüren çeşitli problemlere karşılaşmaya ihtiyaç duymaktadırlar (Bruning vd., 2014).

Problem genişletmenin, beyin temelli öğrenme kuramı açısından da ele alınabileceği ve bu kuramla ilişkili olabileceği de düşünülmektedir. Beyin temelli öğrenme kuramı göre araştırmacılar, öğrenme ile beyin hücreleri arasındaki ilişkiyi inceleyip, öğrenme süreci sonucunda nöronlarda yeni akson iplikçiklerinin oluştuğunu belirtmektedirler. İnsan beyninin işlemler sırasında zorlanması onun gelişimini sağlamaktadır. Buna göre, her öğrenme deneyimi ve çalışması yeni sinaptik bağların oluşması demektir. Öğrenme, beyin temelli öğrenme yaklaşımında, fiziksel uyarılar sonucu beyinde 
gerçekleşen biyokimyasal bir değişimdir. Bununla birlikte beyinde sinaptik bağlantıların birleşerek yeni nöral ağların oluşması, dentrit sayısının çoğalması ve yeni sinapsların oluşması olarak açıklanmaktadır. Bu duruma sinaptik plastisite ya da sinaptik filizlenme denilmektedir (Canbulat, 2016). Problem genişletmenin yapısı itibarı ve problemler arası strateji transferi içerdiğinden, beyin hücreleri arasında yeni bağlantılar oluşturarak, plastisite oluşumuna katk1 sağlayacağı düşünülmektedir. Yapılan araştırmalar doğrultusunda ortaya atılan "sinirlerin esnekliği (neural plasticity, plasticity, neuroplasticity)" kavramı ise öğrenme konusu için büyük bir önem taşımaktadır. Sinirlerin esnekliğini (plastisite) tanımlamak gerekirse; beynin, çevreye karşı olarak yap1 ve kimyasındaki değişme yeteneği olarak tanımlanabilmektedir (Diamond, 1988). Sinirlerin esnekliği diğer bir ifade ile beyindeki sinir ağlarının yeni yaşantı ve deneyimlere bağlı olarak kendi içinde yeniden organize olabilme yeteneğidir. Elde edilen yeni bilgi ve beceriler öğretim süreci veya zihinsel deneyimler yoluyla, beyinde sürekli olarak işlevsel bir değişime neden olmaktadır (Chudler vd., 2000). Problem genişletmenin de rutinleşmiş problem çözme sürecinde buna benzer bir işlevsellik ya da değişim oluşturduğu söylenebilir. Düşünme süreci ne kadar çok uyarıcılarla desteklenir ve geliştirilirse sinapsların ve nöron bağlantılarının o kadar çok zenginleşmesini sağlar. Deneyimlerle bağlantılı olarak bilgimiz bütünlük sağlar, anlam kazanır ve onu içselleştiririz (Duman, 2007).

Transfer (aktarım) konusu problem genişletmenin içerisinde yer alan bileşenlerden biri olarak düşünülebilir. Problem genişletmede çözülen bir problem deki yöntem-stratejinin genişletilmiş probleme aktarımı yani transferi gerçekleştirilir. Bu transferi gerçekleştirmek için çözülen problemde, problemin tam olarak kavranması gerekmektedir. Aktarım çok kritiktir, çünkü o olamadan öğrenme sadece konu ve mekâna (o yere) özgü olur. Öğrencilerin öğrendiklerini farklı içerik ve düzenlere çevirmeleri beklenir (Schunk, 2009).

Problem genişletmenin, Einstellug etkisi denilen problem çözmede aşırı genelleme sorununu gidereceği de düşünülebilir. Bu etki psikoloji alanında ilk olarak Luchins (1942) tarafından tanımlanmış "Einstellung etkisi” denilen, köklü ve ünlü bir olaydır. Bu olay, daha iyi, etkili ve daha uygun yöntemlerle yapılabilmesine rağmen, özelleştirilmiş bir şekilde verilen problemi çözmeye karş1 kişini eğilimi anlamına gelir. Bu davranışı, bir kuralı aşırı genelleme yapacak ve bu kuralı uygun olmayan şekilde kullanacak çocuklarda (ve bazı yetişkinlerde) görürüz. Örneğin;

A 17 birim, B 8 birim, C 5 birim su olan üç sürahin ve bir haznen var. 14 birimlik suyu haznenin içine, ölçerek nasıl koyarsın?

Burada çözüm (A+C-B)'dir. Çözümün ardından çocuklara, içinde her zaman çözümü iki sürahinin kapasitesini toplayıp ve diğerini çıkarmak olan bu tür bir dizi problem verilir. Ve en sonunda şu örnek verilir:

A 32 birim, B 20 birim ve C 8 birim su olan üç sürahi ve bir haznen var. 20 birimlik suyu haznenin içine nasıl ölçerek koyarsın?

İstenen 20 birimi ölçebilmek için B sürahisini kullanabilmelerine rağmen çocukların ve yetişkinlerin çoğu probleme $(\mathrm{A}+\mathrm{C}-\mathrm{B})$ çözümünü verirler. Bu durum Einstellung etkisi olarak tanımlanır (Luchins, 1942). Bu yaratıcı düşünmenin düşmanı olan, düşünmede esnek olmamaya doğru bir eğilimi gösterir. Bu tür esnek olamam eğilimi gösteren çocuklar kuraları uygularlar ama her zaman daha iyi, daha şık, enteresan, daha etkili bir çözüm yolu olabilme ihtimaline karşı didaktiktirler basmakalıp cevaplara ve sıradan işlere daha az güvenirler, matematikte mantıklı riskler almaya daha isteklidirler (Haylock ve Cockburn, 2014). Problem genişletme, bilinen matematiksel problemlerden farklı olduğu için bu şekildeki bir aşırı genelleme sorununa yol açmayacağı düşünülebilir, çünkü genişletilmiş problem her ne kadar ana problemin bir parçası olsa da kullanılan veriler ve yöntem açısından farklılık gösterir.

Problem genişletmenin doğasında var olan, çözülen problemdeki deneyimin yeni probleme aktarılması Ausubel'in (1968) anlamlı öğrenme kuramıyla da ilişkili olduğu düşünülebilir. Bu kuramda; bilinenden bilinmeyene, basitten karmaşığa şeklinde bir hiyerarşi mevcuttur. Ausubel'e göre 
öğrencinin önceki öğrenme yaşantılarında elde ettiği bilgi ve deneyimler, öğretim sürecinin planlanması ve uygulanması sırasında dikkate alınmalı, yeni bilgi ve deneyimler daha öncekilerin üzerine inşa edilerek öğretim gerçekleştirilmelidir. Öğrencinin önceden bildikleri, öğrenmeyi etkileyen en önemli faktördür. Öğrencinin var olan bu bilgileri ortaya çıkarılıp, onlara uygun şekilde öğretim planlanmalıdır. Bilişsel yapıda var olan bilgilerle, yeni öğrenilecek kavram ve bilgiler arasında bir ilişki varsa öğrenme anlamlıdır denilebilir. Anlamlı öğrenme; kavramlar, olaylar ve nesneler arasındaki ilişkinin bir sonucudur. Öğrenci aradaki bu ilişkinin farkında değilse, öğrendiklerini zihnindeki eski bilgileriyle bağ kuramıyorsa ve bütünleştiremiyorsa anlamlı öğrenme gerçekleşemez. Öğrenci tarafından daha önceden öğrenilenlerin doğru ve tam olarak öğrenilmiş olması, anlamlı öğrenmenin bir diğer gereğidir. Bu nedenle eksik ve yanlış bilgiler üzerine anlamlı, yeni bilgiler kurulamaz. Öğrencinin daha önceden öğrendiği bilgiler yanlış ise bu bilgiler yeni bilgilerle bütünleşemeyecektir. Dolayısıyla Öğrencinin zihninde anlamayı sağlayacak kaynaştırma, bağlantı kurma etkinlikleri yapılamayacak ve sonuç olarak yeni bilgiler öğrenilemeyecektir (Çakıcı, Alver ve Ada, 2006).

Problem genişletme uygulamasında, verilen bir problem Polya'nın problem çözme basamaklarına (anlama, planlama, uygulama, değerlendirme) uygun olarak çözülür. Bu basamaklarda problem genişletme açısından en kritik olan basamak kavrama basamağıdır. Ana problemi kavrayamayan bir öğrencinin diğer basamaklarda başarılı olması düşünülemez. Bunun yanında planlama aşaması da önemlidir. Çünkü bu basamakta oluşacak çözüm stratejisi genişletmede de kullanılabilmektedir. Aşağıdaki örnekte bu durum açıkça görülebilir.

Problem 18) Okula bağışlanan 240 kitabın 6/8's1 4-D sınıfına dağıtıldı, 34 tanesi de kütüphaneye verildiğine göre, geriye kaç kitap kalmıştır?

Yukarıdaki problem genişletme uygulama örneğindeki ana problemde, öğrenci problemi okuyup kavradıktan sonra çözüm için stratejiler geliştirecektir. Burada çözüm yollarından biri, kitap sayısının 6/8'sı bulunduktan sonra bunlara kütüphaneye verilen 34 kitap daha eklenip, tüm kitap sayısından çıkarma olabilir. Genişletme soruları:

1) Okula 320 kitap bağışlansaydı, geriye kaç kitap kalırdı?

Genişletmeye geçildiğinde ana problemle genişletme arasında sadece baştaki kitap sayısının değiştiği görülmektedir. Öğrenci burada yeni veriyle ana problemdeki çözüm stratejisini kullanarak çözebilecektir. kalırdi?

2) Kitapların, 3/8 ‘ü 4-D sınıfına dağıtılsa, 86'sı da kütüphaneye verilseydi geriye kaç kitap

Genişletmenin bu bölümünde kesir kısmı ve eksilen kısımlar değiştirilmiştir. Değiş̧en kısımlar incelendiğinde problem de ana problemdeki stratejinin aynı şekilde burada da kullanılabileceği görünmektedir. Burada da strateji transferi söz konusudur. Transfer, bilgi ve becerilerde olduğu gibi stratejilerde de kullanılabilir (Phye, 2001). Problem çözmenin bu aşamasında bazı öğrenciler 1. problem genişletme etkinliğinin üzerine devam etmek gibi bir hata yaptıkları gözlemlenmiştir. Devam eden süreçle beraber her genişletmenin birbirinden bağımsız çözüleceği kavranmıştır.

3) 4-D sınıfina kitaplar dağıtıldıktan sonra, 96 kitap kütüphaneye verebilir miyiz? Neden?

Problem genişletmenin son sorusunda ise öğrenciye genişletilmiş bir problemle beraber üstbilişsel bir soru “neden?" yöneltilmektedir. Öğrenciden burada, ana problem çözümünün ilk basamağını hatırlaması ve ardından ikinci kısımdaki yeni değerin uygun olup olmadığını düşünerek fark etmesi beklenmektedir. Bu kısma üstbilişteki "neyi nasıl yaptığının farkında olmak" olarak bakılabilir (Özsoy ve Ataman, 2009). 


\section{Üstbiliş}

Üstbiliş, insanların kendi düşünme süreçleriyle ilgili bilgileridir (Bruning vd., 2014). Özsoy ve Ataman'a (2009) göre, kişinin kendi zihinsel faaliyetlerini gözleyebilmesi, izleyebilmesi ve kendi öğrenmesini denetlemesi gibi yetenekler, üstbiliş becerilerini oluşturmaktadır. Üstbiliş kavramı ilk defa Flavell tarafından 1970'li yıllarda kullanılmıştır (Flavell, 1979). Üstbiliş, kişinin kendi düşünme süreçlerinin farkında olması ve bu düşünme süreçlerini kontrol edebilmesi anlamına gelir (Akın, Abacı ve Çetin, 2007; Desoete ve Özsoy, 2009). Üstbiliş; planlama ve stratejiler seçme, öğrenme sürecinin farkında olunması ve bu süreci izlemesi, kişinin kendi hatalarını düzeltebilmesi ve kullandığı stratejilerin işe yarayıp yaramadığını kontrol edebilmesidir (Hacker ve Dunlosky, 2003). Ayrıca gerektiğinde öğrenme yöntemini ve stratejilerini değiştirebilme gibi yeteneklere sahip olmayı da beraberinde getirir (Larkin, 2010). Öğrenmenin etkili olması için kişinin bunu bilinçli olarak yapması gereklidir (Morin, 2003). Nitekim eğitim alanında yapılan araştırmalar da bu düşünceyi desteklemektedir (Erdoğan ve Şengül, 2017). Yapılan çalışmalar doğrultusunda, öğrencilere üstbiliş stratejilerini kazandırmaya dönük bir öğretim yapılmasının, matematik öğretiminde genel anlamda öğrencilerin başarısının artacağına, matematiğe karşı olumlu tutum geliştireceğine ve bilgilerin kalıcılığına katkı sağlayacağı düşünülmektedir. Matematik öğretiminin etkili biçimde yapılmasında, öğrencilere matematiksel beceriler kazandırılmasında, öğretimin kalıcı, eğlenceli ve faydalı olmasında üstbiliş stratejilerinin büyük katk1 sağlayacağı düşünülmektedir. Problem genişletme de bilişsel kuramın 'analiz' basamağını oluşturduğundan, üstbilişsel bir beceridir denilebilir (Özsoy ve Ataman, 2009). Ayrıca, üstbilişsel yeteneğin öğrencilerin problem çözme konusundaki başarıları ve yeterlilikleri üzerinde doğrudan etkisi vardır (Bingölbali, Özmantar ve Alacaci, 2009).

Öğrencilerin çözdükleri bir problemle ilgili yeni bağlantılar oluşturmaları, probleme farklı veriler eklemeleri gibi genişletmeler öğrencilerin düşünme becerileri ve üretkenliklerini etkileyeceği düşünülmektedir. Bir problemi çözen öğrenciye, 'Problemde .... olsa ne olurdu?' gibi varsayımlı sorularla problemi genişleterek, var olan bilgi ve strateji birikimini genişletilmiş probleme aktararak, öğrenciyi farklı düşünme yollarına yönlendirmenin faydalı olacağı önerilmektedir (Van de Walle vd., 2010).

$\mathrm{Bu}$ araştırmada, problem genişletme etkinliklerinin problem çözme becerilerini ve diğer yandan kendi bilişsel süreçlerinin farkında olması anlamına gelen üstbilişsel yeteneklerini geliştirebileceği öngörülmüştür. Bununla birlikte öğrencilerin düşünme ve yeni yollar keşfetme becerilerinin de artacağı öngörülmektedir. Öte yandan, ilgili literatür taramasında, Türkçe ve yabancı kaynaklarda, problem genişletme (problem extending) başlığı altında, daha önce yapılmış bir çalışmaya rastlanmamıştır. Fakat bazı araştırmalarda 'problemi değiştirme' ve 'problemi genişletme' şeklinde, problem çözme ve kurma konuları içinde, değişik biçimlerde yer aldığı görülmektedir. Araştırmanın problem çözmeye farklı bir boyut kazandıracağı, katkı sağlayacağı ve özellikle Polya'nın (1981) problem çözme sürecinin son aşaması olarak tanımlanan kontrol basamağına yeni bir bakış açısı kazandırabileceği düşünülmektedir.

Araştırmanın problemi: "Problem Genişletme Etkinliklerinin Problem çözme ve Üstbilişe Etkisi var mıdır?" olarak düzenlenmiştir. Yapılan araştırmanın problemine cevap bulabilmek için aşağıdaki alt problemler sınanmıştır.

Alt Problemler:

- Problem Genişletme etkinliklerinin uygulandığı deney grubu öğrencileri ile kontrol grubu öğrencilerinin Problem Çözme Başarı Testinden aldıkları puanlar açısından aralarında anlamlı bir farklılık var midir?

- Problem genişletme etkinliklerinin uygulandığı deney grubu öğrencileri ile kontrol grubu öğrencilerinin Üstbilişsel Bilgi ve Beceri Testinden aldıkları puanlar arasında anlamlı bir farklılık var midır? 


\section{Araştırmanın Amacı ve Önemi}

$\mathrm{Bu}$ çalışmanın amacı: Problem genişletme etkinliklerinin problem çözme ve üstbiliş becerilerine etkisini incelemektir. Problem genişletme çalışmalarıyla gerçekleştirilecek matematik öğretiminin, öğrencilerin problem çözme başarılarına ve üstbiliş becerilerine katkı sağlayacağı düşünülmektedir. Çünkü çözülen bir problem, farklı sorularla genişletildiğinde, öğrencilerin var olan bilgi ve strateji birikimini yeni duruma daha kolay aktaracağı görülecektir. Bununla birlikte, öğrencinin genişletilmiş problemde, probleme birçok değişik açıdan bakarak ne yaptığını ve nasıl yaptığını daha iyi kavrayacağı düşünülmektedir. Üstbiliş öğrencinin ne bildiğinin ve ne yaptığının farkında olması olarak açıklanmaktadır. Bundan dolayı problem genişletme uygulamalarındaki oluşması beklenen stratejik tecrübe birikimin ve zihinsel farkındalı̆̆ın, öğrencilerin üstbiliş becerileri üzerinde olumlu etkiler göstereceği varsayılmaktadır.

Araştırmaya konu olan problemin önemi; MEB (2015) matematik programında "Problem genişletme etkinlikleri, problem çözme başarısında en önemli faktörlerden birisi olan tecrübe gelişimine, strateji birikimine ve bu birikimin sonraki durumlara transfer edilmesini sağlamaya önemli katkılar getirecektir." şeklinde problem genişletmeden bahsedilmektedir. Programda bu şekilde değinilmesine rağmen literatürde problem genişletmenin ne olduğuna yönelik bir tanım ya da problem genişletmeye yönelik örnekler detaylı biçimde bulunmamaktadır. Literatürde bulunan bu boşluğu doldurmaya yardımcı olmak, bu konuda araştırma yapacaklara ve problem genişletme etkinliği düzenleyecekler için örnek olmak bu araştırmanın önemini olarak görülebilir. Bununla birlikte, öğrencilerin problemi anlama, problemde istenenleri belirleme ve çözme surasında genellikle zorlandıkları görülmektedir. Bu araştırmada, öğretim ilkelerindeki 'basitten karmaşı̆̆a' ve 'bilinenden bilinmeyene' ilkesinden hareketle, öğrencilerin çözdüğü bir problem üzerinde değişiklikler yapılıp, problem genişletilerek öğrencilerin problem çözme etkinliklerinde daha başarılı olacakları varsayılmaktadır (Demirel, 2010). Mevcut problem çözme süreçlerinde, problem çözüldükten sonra yeni bir probleme geçilir. Bu durumda oluşan bilgi ve strateji birikimi unutulmaktadır. Problem genişletme yönteminde, çözülen problemdeki bilgi ve strateji birikimi yeni biçimlerde kullanılacağından, bu sayede zayıf durumdaki öğrencilerinde strateji gelişimi sağlanacağı düşünülmektedir. Bununla birlikte 'Problem Genişletme' başlığı altında daha önce bir araştırma olmadığından bundan sonraki araştırmalar içinde örnek teşkil edeceği umulmaktadır.

Problem genişletmede, çözülen bir problem farklı sorularla genişletilerek, öğrencilerin var olan bilgi ve strateji birikimini yeni duruma daha kolay aktarması sağlanır. Bu yöntemde problem çözme sürecinde öğrencinin ne yaptığının daha çok farkında olduğu düşünülmektedir. Bundan dolayı problem genişletme yapısı itibariyle üst düzey zihinsel davranışlar gerektiren bir beceridir. Araştırmanın deney grubunda yürütülen dokuz haftalık uygulama süreci, Problem genişletme becerilerinin tam olarak gelişmesi için yeterli olmayabilir. Ancak araştırma süreci planlanırken, problem çözme üzerine daha önce yapılan çalışmalardaki uygulama zamanları da incelenmiştir. Bunun sonucunda uygulama için ayrılan sürenin sonunda öğrencilerin üstbilişsel bilgi ve beceriler bakımından ölçülebilecek düzeyde değişim gösterebilecekleri düşünülmüş ve böyle bir değişim için uygulanan öğretim etkinliklerinin ve dokuz haftalık öğretim süresinin yeterli olduğu varsayılmıştır. Ayrıca Problem Çözme Başarı Testindeki çoktan seçmeli soruların problem çözme başarısını ölçebileceği varsayılmaktadır. Diğer yandan bu araştırma;

- 31 deney ve 30 kontrol olmak üzere 2 grupla,

- 2015-2016 eğitim öğretim yılı ikinci yarıyılında müfredattaki 4. Sınıf 4 işlem problemleri ve genişletmeleriyle,

- 15 soruluk, çoktan seçmeli, problem çözme başarı testleriyle,

- Üstbilişsel bilgi ve beceri ölçeğinin oluşturulmasında esas alınan üstbiliş becerileri; tahmin, planlama, izleme ve kontrol ile sinırlıdır. 


\section{Yöntem}

\section{Araştırmanın Modeli}

$\mathrm{Bu}$ araştırma, yarı deneysel bir araştırmadır. Bu doğrultuda araştırma, ön test-son test kontrol gruplu, yarı deneysel desen üzerine modellenmiştir (Tablo 1).

Tablo 1

Araștırma Modeli

\begin{tabular}{|c|c|c|c|}
\hline Gruplar & Ön Test & Uygulama & Son Test \\
\hline Deney & Problem Çözme Başarı & \multirow{4}{*}{$\begin{array}{l}\text { Uygulama } \\
\text { (Problem Genişletme } \\
\text { etkinlikleri yoluyla } \\
\text { problem çözümü } \\
\text { uygulaması) }\end{array}$} & Problem Çözme Başarı \\
\hline \multirow[t]{3}{*}{ Grubu } & Testi (Ön test) & & Testi (Son test) \\
\hline & Üstbilişsel Bilgi ve Beceri & & Üstbilişsel Bilgi ve \\
\hline & Ölçeği (Ön test) & & Beceri Ölçeği (Son test) \\
\hline \multirow[t]{2}{*}{$\begin{array}{l}\text { Kontrol } \\
\text { Grubu }\end{array}$} & $\begin{array}{l}\text { Problem Çözme Başarı } \\
\text { Testi (Ön test) }\end{array}$ & \multirow[t]{2}{*}{ Var olan normal süreç. } & $\begin{array}{l}\text { Problem Çözme Başarı } \\
\text { Testi (Son test) }\end{array}$ \\
\hline & $\begin{array}{l}\text { Üstbilişsel Bilgi ve Beceri } \\
\text { Ölçeği (Ön test) }\end{array}$ & & $\begin{array}{l}\text { Üstbilişsel Bilgi ve } \\
\text { Beceri Ölçeği (Son test) }\end{array}$ \\
\hline
\end{tabular}

\section{Evren ve Örneklem}

Araştırma, 2015-2016 öğretim yılının ikinci yarıyılında Rize ili Merkez ilçesindeki bir ilkokulda, deney grubunda 31 kontrol grubunda 30 öğrenci olmak üzere 61 öğrenci üzerinde yürütülmüştür. Araştırma için ilgili makamlardan gerekli izinler resmi yazışma yoluyla alınmıştır. Grupların birbirlerine denkliklerine, araştırmacı tarafından geliştirilmiş olan Problem Çözme Başarı Testi ile bakılıp, buna göre 1 deney, 1 kontrol grubu oluşturulmuştur. Seçilen deney grubunda problem genişletme çalışmalarıyla, problem çözme etkinlikleri yapılmıştır. Deney grubu \%48'i kız, \%52'si ise erkek olmak üzere toplam 31 öğrenciden oluşmuştur. Kontrol grubunda ise \%57'si kı, \%43'ü erkek olmak üzere toplam 30 öğrenci bulunmaktadır. Deney ve kontrol grupları belirlenirken öğrencilerin içinde bulundukları sınıfların grup olarak alınmasının sebebi, bu sınıfların Millî Eğitim Bakanlığı sistemi içinde önceden oluşturulmuş ve yapılandırılmış olmasıdır. Mevcut sınıf düzenleri bozulmadan, sistem içindeki imkânlar dâhilinde grupların denkliğini araştırmak amacıyla gruplar bazı nitelikleri bakımından karşılaştırılmıştır. Bu amaçla önce okul yöneticileri ve sınıf öğretmenleri ile görüşülmüş ve bu yetkililer tarafından, genel başarıları bakımından iki sınıf arasında bir fark olmadığı sözlü olarak belirtilmiştir.

\section{Veri Toplama Araçları}

Araştırmada öğrencilere, Problem Çözme Başarı Testi ile Üstbiliş Bilgi ve Becerileri Ölçeği uygulanmıştır. Bu ölçek ve testler öğrencilere araştırmadan önce ön-test, araştırmadan sonra da sontest olarak uygulanmıştır.

\section{Problem Çözme Başarı Testi}

Araştırmanın bağımlı değiş̧keni olan problem çözme başarısını ölçmek amacıyla hazırlanan Problem Çözme Başarı Testi araştırmacı tarafından 2015-2016 yılında MEB'in 4. Sınıf matematik ders kitabı baz alınarak geliştirilmiştir. Testi cevaplayan öğrenciler arasındaki matematiksel bilgi farklılıklarının etkisini en aza indirebilmek için bu testte sadece dört işlem (toplama, çıkarma, çarpma, bölme) yardımıyla çözülebilecek sorulara yer verilmiştir. Problem Çözme Başarı Testi hazırlama aşamasında, araştırmacı tarafından örnek 20 soru hazırlanmıştır. Daha sonra bu sorular 25 öğrenci üzerinde uygulanmış ve soruların madde güçlük ve ayırıcılık indeksine bakılarak içinden en uygun olan 15 soru seçilerek gruplara uygulanmıştır. Ayrıca 2015-2016 yılında uygulanan ilkokul 4. sınıf matematik programına uygun olmasına dikkat edilmiştir. 
Tablo 2

Problem Çözme Başarı Testi Analiz Sonuçları

\begin{tabular}{ccccc}
\hline$N$ & Soru Sayıs1 & $\begin{array}{c}\text { Testin Ortalama } \\
\text { Güçlüğü }\end{array}$ & $\begin{array}{c}\text { Testin Ortalama } \\
\text { Ayırıcılığ } 1\end{array}$ & KR-20 \\
\hline 25 & 20 & 0.67 & 0.54 & 0.87 \\
\hline
\end{tabular}

Tablo 2'de belirtildiği gibi 20 maddeden oluşan Problem Çözme Başarı Testi'nin KR-20 güvenirliği .87; ortalama ayrıcılığı .54 ve ortalama güçlüğü .67 olarak hesaplanmıştır. Bu değerler doğrultusunda testin uygun bir veri toplama aracı olduğuna karar verilmiştir.

\section{Üstbilişsel Bilgi ve Beceri Ölçeği}

$\mathrm{Bu}$ araştırmada öğrencilerin üstbiliş düzeylerinin ölçülmesi için, Üstbilişsel Bilgi ve Beceri Ölçeği (Ozsoy ve Ataman, 2009) kullanılmıştır. Üstbilişsel bilgi ve beceri ölçeği temelde, üstbilişsel bilgi (yordam bilgisi, bildirimsel bilgi ve durum bilgisi) ve üstbilişsel kontrol (tahmin, planlama, izleme, değerlendirme) becerilerini ölçmeye dayanmaktadır. Toplam 58 maddeden oluşan ölçekteki maddelerin 30'u üstbilişsel bilgiyi, 28'i de üstbilişsel kontrolü yoklamayı amaçlamaktadır. Bir öğrencinin minimum sıfır, maksimum 122 puan alabildiği bu ölçekte aynı zamanda üstbilişsel bilgi ve üstbilişsel kontrolün alt bölümlerini oluşturan; tahmin/değerlendirme, planlama, izleme, bildirimsel bilgi, durum bilgisi ve yordam bilgisi puanları da elde edilebilmektedir. Ölçeğin güvenirlik değerleri; bildirimsel bilgi için $\alpha=.71$; yordam bilgisi için $\alpha=.70$; durum bilgisi için $\alpha=.79$; tahmin için $\alpha=.73$; planlama için $\alpha=.78$; izleme için $\alpha=.80$ ve değerlendirme için $\alpha=.76$ olarak bulunmuştur. Ölçeğin test-tekrar test güvenirliği ise $r=.85$ ( $p<.05$ ) olarak elde edilmiştir (Ozsoy ve Ataman, 2009).

\section{Araştırma Sürecinde Yapılan Uygulamalar}

\section{Deney Grubundan Yürütülen Çalışmalar}

Uygulama sürecinde deney grubundaki öğrencilere problem genişletmenin öğrenciler tarafından kavranması için 40 dakikalık hazırlık dersi yapılmıştır. Hazırlık dersinde öğrencilere örnek üzerinde sürecin nasıl uygulanacağı, problem çözme basamakları anlatılmıştır. Deney grubunda yürütülen tüm çalışmalar, hazırlanan sorular, uzmanların, uygulayıcının görüşleri ve öğrencilerden gelen dönütlere göre araştırmacı tarafından geliştirilmiştir. Problem genişletme etkinlikleri, benzer bir örneği olmadığından tamamı araştırmacı tarafından uzman görüşlerine başvurularak hazırlanmıştır. Uygulama bilgilendirme ve tanıtımla birlikte, 9 hafta (19 ders saati) sürmüştür. Uygulamanın yapıldığ 18 ders saati boyunca 26 adet problem genişletme etkinliği uygulanmıştır. Haftada 2 ders olarak uygulanan problem genişletme çalışmaları, bazen hafta da 2 çalışma bazen de haftada 3 çalışma olarak uygulanmıştır. Etkinlikler genellikle 1 ana problem ve hemen ardından 3 problem genişletme şeklinde düzenlenmiştir. Bazı etkinliklerde genişletme sayısı 2 olarak düzenlenmiştir. Ana problemin çözümü Polya'nın problem çözme başmaklarına göre (kavrama, plan yapma, uygulama-çözüm, değerlendirme) olarak düzenlenmiştir. Problem genişletme kısmında ise bu adımlara ayrıca yer verilmemiş, genişletme ana problemin bir parçası olduğundan gerek duyulmamıştır.

Deney grubundaki uygulamalar araştırmacı dışında bir sınıf öğretmeni tarafından yürütülmüş ve dersler araştırmacı tarafından gözlenmiştir. Uygulamalarda ana problemin öğrenciler tarafından çözülmesi istenmiş, ardından problem genişletmeye geçişmiştir. Sınıf seviyesinin üzerinde olan öğrencilere ana problemin çözümünün ve kontrolünün ardından problem genişletmelerini de yapmalarına izin verilmiştir. Diğer öğrenciler için de çözüm için yeterli süre verildikten sonra ana problem tahtada çözülmüş ardın problem genişletme kısmına geçmeleri sağlanmıştır. Uygulamanın ilk haftalarında, problem genişletme sorulanın 2. ya da 3. sorularında bazı öğrencilerin her genişletme sorusunda ana problemden hareket edeceğini unutarak, genişletmeyi 1. problem genişletme sorusu üzerine devam ettirdikleri görülmüsstür. Bu sorun 2. ve 3. haftadan sonra, her problemle genişletmenin birbirinden bağımsız çözülmesi gerektiğinin anlatılması ve uygulamanın kavranmasıyla hemen hemen ortadan kalkmıştır. 


\section{Kontrol Grubunda Yürütülen Çalışmalar}

Kontrol grubunda, kontrol grubu öğretmenine problem genişletme hakkında herhangi bir bilgi verilmemiş, gruba Problem Çözme Başarı Öntesti ve Üstbilişsel Bilgi ve Beceri Testi uygulanmıştır. Kontrol grubunda mevcut matematik programına göre derslere devam edilmiştir. Deney grubuna uygulanan 9 haftalık uygulamadan sonra kontrol grubuna da Problem Çözme Başarı Testi ile Üstbilişsel Bilgi ve Beceri Testi son test olarak aynı hafta uygulanmıştır. Ardından elde edilen sonuçlar istatistik tablolarına dönüştürülerek analiz edilmiştir.

\section{Verilerin Analizi}

Verilerin normal dağılım kontrolü Kolmogorov-Smirnov testi ile yapılmıştır. Grup varyanslarının homojenlik kontrolü Levene testi ile yapılmıştır. Varsayımları yerine getiren değişkenlerin karşılaştırılmasında üç faktörlü faktörlerden birinin seviyeleri tekrarlanan ölçümlü varyans analizi kullanılmıştır. Tekrarlanan ölçümler zaman faktörünün seviyelerinde dikkate alınmıştır (ön-test, son-test). Farklı ortalamalar Tukey çoklu karşılaştırma testi ile belirlenmiş sonuçları harfli gösterim şeklinde ifade edilmiştir. Varsayımları yerine getirmeyen değişkenlerin karşılaştırılmasında bağımsız iki grup için Mann-Whitney U-testi, bağımlı iki grup için Wilcoxon Sıralı işaret testi kullanılmıştır. Değişkenlerin ortalama \pm standart hata, standart sapma, medyan ve en düşük-en yüksek değer gibi tanıtıcı istatistik değerleri hesaplanmıştır. Değişkenler arasındaki ilişkilerin belirlenmesi amacıyla korelasyon analizi yapılmış ve Spearman korelasyon katsayıları hesaplanmıştır. Verilerin analizinde ve sonuçların yorumlanmasında $\% 5$ önem düzeyi dikkate alınmıştır.

Ayrıca araştırmanın analizlerinden hareketle sonuçların etki büyüklüğü hesaplanmıştır. İki grubun ortalamaları arasındaki farkın hesaplandığı istatistiksel yöntemlerde (tek grup t-test, ilişkili örneklemler için t-testi, ilişkisiz örneklemler için t-test, vb.) için gerekli olan etki büyüklüğü hesaplanmasında Cohen's $d$ formülü (Cohen, 1988) yaygın şekilde tercih edilmektedir. Hesaplamalar sonucunda elde edilen $d$ değeri şu şekilde yorumlanır: $\mathrm{d} \leq 0.20$ küçük etki büyüklüğü; $0.20<d<0.80$ orta; $d \geq 0.80$ ise büyük etki büyüklüğü (Cohen, 1988). Ayrıca Cohen's $d$ değeri aynı zamanda çalışılan örneklem büyüklügünün kestirilmesi için de kullanılmaktadır. Cohen's $d$ formülü ile elde edilen hesaplamalardaki küçük etki büyüklükleri, daha büyük örneklem kullanmanın gerekliliğini gösterir (Özsoy ve Özsoy, 2013).

\section{Bulgular}

$\mathrm{Bu}$ bölümde, araştırmadan elde edilen veriler istatistiksel tekniklerle analiz edilmiş, elde edilen bulgular alt problemler dikkate alınarak sunulmuş ve yorumlanmıştır.

\section{Birinci Alt Probleme İlişkin Bulgular ve Yorum}

Deney ve kontrol grubu öğrencilerinin Problem Çözme Başarı Testi puanları bakımından ön-test ve son-test puanları arasında anlamlı fark olup olmadığı, t-testi ile incelenmiş ve sonuçlar Tablo 3 'te sunulmuştur.

Tablo 3

Problem Çözme Başarı Testi sonuçlarına ait tanıtıcı istatistik değerleri ve karşılaşstırma sonuçları

\begin{tabular}{|c|c|c|c|c|c|c|c|c|c|}
\hline Grup & Test & $\mathrm{N}$ & $\bar{x}$ & $S$ & $\bar{X}_{\text {gon }}-\bar{X}_{0 n}$ & sd & $\mathrm{t}$ & $\mathrm{p}$ & Cohen's d \\
\hline \multirow{2}{*}{ Deney } & $\begin{array}{l}\text { Ön } \\
\text { Test }\end{array}$ & 31 & 10.839 & 3.769 & \multirow{2}{*}{1.419} & \multirow{2}{*}{30} & \multirow{2}{*}{-3.54} & \multirow{2}{*}{$.001 *$} & \multirow{2}{*}{.284} \\
\hline & $\begin{array}{l}\text { Son } \\
\text { Test }\end{array}$ & 31 & 12.258 & 3.821 & & & & & \\
\hline \multirow{2}{*}{ Kontrol } & $\begin{array}{l}\text { Ön } \\
\text { Test }\end{array}$ & 30 & 11.300 & 3.109 & \multirow{2}{*}{-0.100} & \multirow{2}{*}{29} & \multirow{2}{*}{0.24} & \multirow{2}{*}{0.811} & \\
\hline & $\begin{array}{l}\text { Son } \\
\text { Test }\end{array}$ & 30 & 11.200 & 3.624 & & & & & \\
\hline
\end{tabular}

$* p<.05$ 
Tablo 3 incelendiğinde Problem Çözme Başarı Testi ön-test ortalamaları, deney grubunda $\bar{X}_{=10.84}(S=3.77)$ iken, kontrol grubunda $\vec{X}_{=11.30}(S=3.11)$ olarak gerçekleşmiştir. Bu durum problem çözme ön-test puanlarında kontrol grubunun daha yüksek ortalamaya sahip olduğu görülmektedir. Bununla birlikte son-test ortalamalarına bakıldığında deney grubu $\bar{X}_{=12.26}(S=3.82)$ kontrol grubu ise $\bar{X}_{=11.20}(S=3.62)$ olarak gerçekleşmiştir. Ortalamalar incelendiğinde deneysel uygulama sonrasında ortalama puanların deney grubu lehine artı̧̧ gösterdiği görülmektedir. Burada dikkat çekici bir nokta ise kontrol grubu puanlarındaki düşüştür. Problem Çözme Başarı Testi bakımından yapılan eş-yapma t-testi sonucunda deney grubunda ön-test ve son-test puan ortalamaları arasındaki farklıl1k istatistiksel olarak anlamlı bulunmuştur $(p<.01)$. Deney grubunda son test ortalaması ön-testten yüksektir. Kontrol grubunda ise Problem Çözme Başarı Testinin ön-test ve son-test ortalamaları arasındaki farklılık istatistiksel olarak anlamlı bulunmamıştır $(p>.01)$. Bu problemin bulgularında Cohen's $d$ değeri 0.284 olarak bulunmuştur. Bu durum etki büyüklüğü açısından orta derecede olarak görülmektedir. Etki büyüklüğü değerinin küçük etki büyüklüğü değerine yakın olması, araştırmanın örnekleminin sınır seviyede olmasından kaynaklandığı düşünülebilir.

\section{İkinci Alt Probleme İlișkin Bulgular ve Yorum}

Problem genişletme etkinliklerinin uygulandığı deney grubu öğrencileri ile kontrol grubu öğrencilerinin Üstbilişsel Bilgi ve Beceri Testinden aldıkları ön-test ve son-test puanlarının karşılaştırmalı analizi Tablo 4'te gösterilmiştir.

Tablo 4

Üstbiliş̧ Bilgi ve Beceri Ölçeği sonuçlarına ait tanıtıcı istatistik değerleri ve karşılaştırma sonuçları

\begin{tabular}{|c|c|c|c|c|c|c|c|c|c|}
\hline Grup & Test & $\mathrm{N}$ & $\bar{x}$ & $s_{X}$ & $\bar{X}_{\text {on }}-\bar{X}_{\text {son }}$ & sd & $\mathrm{t}$ & $\mathrm{p}$ & Cohen's d \\
\hline \multirow{2}{*}{ Deney } & $\begin{array}{l}\text { Ön } \\
\text { Test }\end{array}$ & 31 & 65.42 & 13.50 & \multirow{2}{*}{12.65} & \multirow{2}{*}{30} & \multirow{2}{*}{7.87} & \multirow{2}{*}{$0.000 *$} & \multirow{2}{*}{-0.09} \\
\hline & $\begin{array}{l}\text { Son } \\
\text { Test }\end{array}$ & 31 & 78.06 & 15.54 & & & & & \\
\hline \multirow{2}{*}{ Kontrol } & $\begin{array}{l}\text { Ön } \\
\text { Test }\end{array}$ & 30 & 72.67 & 10.80 & \multirow{2}{*}{6.63} & \multirow{2}{*}{29} & \multirow{2}{*}{3.74} & \multirow{2}{*}{$0.001^{*}$} & \\
\hline & $\begin{array}{l}\text { Son } \\
\text { Test }\end{array}$ & 30 & 79.30 & 8.36 & & & & & \\
\hline
\end{tabular}

$* p<.01$

Tablo 4 incelendiğinde, Üstbilişsel Bilgi ve Beceri Ölçeği ön-test ortalamaları, deney grubunda $\bar{x}_{=65.42}(S=13.50)$ iken, kontrol grubunda $\bar{x}_{=72.67}(S=10.80)$ olarak gerçekleşmiştir. Bu sonuçlarda ön-test puanlarında kontrol grubunun daha yüksek ortalamaya sahip olduğu görülmektedir. Bunun yanında son-test ortalamalarına bakıldığında deney grubu, $\bar{x}=78.06(S=15.54)$ kontrol grubu ise ortalama $\bar{x}=79.30(S=8.36)$ olarak gerçekleşmiştir. Ortalamalar incelendiğinde her iki grupta da ön-test ile son-test puanlarında artış olduğu görülmektedir. Deney grubundaki artı̧̧ ( $\overline{\bar{X}}_{\left.\text {Son- }-\bar{x}_{\text {Ön }}\right)} 12.65$ puan iken kontrol grubunda ise $\left(\bar{x}_{\text {Son- }} \bar{x}_{\ddot{O}}\right) 6.63$ olarak gerçekleşmiştir. Ortalamalar arasındaki farkların anlamlılı̆̆ını incelemek için yapılan t-testi sonucunda deney $(t=7.87, p<.01)$ ve kontrol $(t=3.74$, $p<.01)$ gruplarında ön-test son-test ortalamalar arasındaki fark istatistiksel olarak anlamlı bulunmuştur. Bulgulara göre, etki büyüklügü olan Cohen's $d$ değeri -0.09 olarak görülmektedir. Bu durum etki büyüklüğ̈̈ açısından hem küçük hem de kontrol grubu lehine görülmektedir. Bu durumun etki büyüklüğü değerinin Cohen's $d$ 'nin 0.20 'den küçük olması ve aynı zamanda bu değerin negatif çıkması, problem genişletmenin üstbiliş üzerinde düşük etki büyüklüğüne sahiptir denilebilir. $\mathrm{Bu}$ durum, örneklemin oldukça küçük olmasından kaynaklanabilir.

\section{Sonuç, Tartışma ve Öneriler}

$\mathrm{Bu}$ araştırmada, ilkokul dördüncü sınıf öğrencilerine problem genişletme etkinliklerinin, problem çözme ve üstbiliş becerilerine etkisinin ölçülmesi amaçlanan bir öğretim süreci uygulanmiştır. 
Araştırmanın birinci alt problemi; "Problem Genişletme Etkinliklerinin uygulandığ 1 deney grubu öğrencileri ile kontrol grubu öğrencilerinin Problem Çözme Başarı Testinden aldıkları puanlar açısından aralarında anlamlı bir farklılık var mıdır?" şeklinde düzenlenmiştir. Araştırma sonuçları değerlendirildiğinde problem genişletme etkinliklerinin problem çözme başarısı bakımından deney grubu lehine anlamlı bir artışa neden olduğu söylenebilir. Ancak bu artışın düşük bir etki büyüklügüne sahip olduğu görülmektedir. Daha geniş bir çalışma grubu ile çalış1lması durumunda etki durumu daha sağlıklı biçimde gözlenebilir.

Polya (1988) problem çözme adımlarının yanında çözüme ulaşılıp değerlendirme yapıldıktan sonra mevcut problemle ilgili ek çalışmalar yapılabileceğinden bahsetmiştir. Van de Walle ve arkadaşları (2010) da benzer bir yaklaşımı önermekte; problemin çözümünün ardından temel probleme, farklı sorular eklenmesini tavsiye etmekte ve genişletme yaklaşımından bahsetmektedir. Literatür incelendiğinde bu önerilerin tavsiye olarak kaldığ 1 , bu konu üzerinde detaylı çalışma yapılmadığı görülmektedir. Diğer yandan Van de Walle ve arkadaşları genişletmenin özellikle sınıf seviyesinin üstünde olan ve problemini diğer öğrencilerden daha önce çözen öğrenciler için daha yararlı olacağını belirtmektedir. Bu araştırmanın uygulama safhasında da sınıf seviyesinin üstündeki öğrenciler üzerinde problem genişletmenin daha etkili olduğu gözlemlenmiştir. Buna karşın uygulama sırasında, ana problemi çözmekte zorlanan veya çözemeyen zayıf öğrencilere, ana problemin çözümü, çözüm stratejisi kavratıldıktan sonra genişletilmiş probleme mevcut stratejiyi aktarabildikleri gözlemlenmiş̧ir. Deney grubunda ön-test ve son-test arasındaki farkın bu sebepten kaynaklandığ1 düşünülebilir. $\mathrm{Bu}$ araştırmada bir alt problem olarak ele alınmamış olmasına rağmen araştırmanın uygulama safhasında problem genişletme etkinliklerinin öğrenciler üzerinde problem çözmeye karşı olumlu tutum geliştirdiği gözlenmiştir. Problem genişletmenin, öğrencilerin problem çözmeye karş1 tutumu ve zayıf öğrenciler üzerindeki etkisini incelemek gelecek araştırmaların konusu olabilir.

Problem çözme, birçok kurum ve araştırmacı tarafindan (MEB, 2015; NCTM, 2000; Polya, 1981; Van de Walle vd., 2010) matematik öğretiminin en önemli amacı ya da amaçları arasında gösterilmektedir. Problem çözme üzerine birçok araştırma yapılmıştır. Bu çalışmada ise matematik öğretimin en önemli amacı olan problem çözme becerisini geliştirmek için "problem genişletme" yaklaşımı denenmiştir. Bu yaklaşımda ana problemi anlamadan, çözüm stratejisi belirlenmeden ve tam olarak çözülmeden problem genişletmeye geçilemez. Problem genişletme çalışmalarında, problemde verilenlere yönelik olarak “... olsa ne olurdu?” sorusuyla, çoğunlukla aynı strateji farklı verilerle yeni durumlara uygulanır. Bu durum, uygulanan stratejinin pekiştirilmesi olarak da görülebilir.

Bir diğer açıdan bazı çalışmalarda (Akay, 2006; Mamona-Downs, 1993; Turhan, 2011) Polya'nın problem çözme basamaklarının beşincisi olarak "problem kurma" gösterilmektedir. Problem genişletme, problem çözme içinde, ana problemin bir parçası/devamı olduğundan, Polya'nın problem çözme basamaklarında yer alması önerilebilir. Problem çözümünde değerlendirme basamağından sonra ya da bu basamak içinde problem genişletme çalışmalarına yer verilmesinin problem çözme becerisinin gelişiminde fayda sağladığı görülmektedir. Problem kurma her ne kadar problem çözme içinde görülse de yapı olarak problem çözmeden farklı olarak düşünülebilir. Problem genişletme, temel problemin çözümünün ve değerlendirme basamağının da uygulanmasının ardından ana problemle işimizin daha bitmediğini bize gösterir. Öte yandan tartışılması gereken hususlardan birisi de problem genişletme yaklaşımının Polya'nın problem çözme basamaklarından en çok hangisi üzerinde etkili olacağı sorusudur.

Bir diğer açıdan, problem genişletmede öğrencinin belli bir bilgi birikimi ve strateji bilgisine sahip olması gerekmektedir. King (1991) tarafından problem çözme üzerine yapılan araştırmada görüldüğü üzere, strateji bilmenin problem çözme becerisine olumlu katkısı olduğu görülmüştür. $\mathrm{Bu}$ araştırmayı destekler şekilde problem genişletmenin bir bakımdan problem çözme stratejilerini daha kalıcı hale getirdiği düşünülebilir. Strateji eğitiminin problem çözme başarısına etkisi, Yazgan ve Bintaş'ın (2005) araştırmasında da görülmektedir. Problem genişletmede tecrübe gelişimi, strateji birikimi ve kullanılan problem çözme yöntem bilgisi sonraki problem durumlarına transfer edilmesi gerekmektedir. 
Araştırmanın ikinci alt problemi; "problem genişletme etkinliklerinin uygulandığı deney grubu öğrencileri ile kontrol grubu öğrencilerinin Üstbilişsel Bilgi ve Beceri Testinden aldıkları puanlar arasında anlamlı bir farklılık var mıdır?" şeklinde düzenlenmiştir. Bu araştırma sonuçlarına göre, problem genişletme etkinlikleri sonunda üstbiliş puanları bakımından deney grubu lehine anlamlı fark ortaya çıkmıştır. Ancak farkın etki büyüklügü oldukça düşük seviyededir. Problem genişletme, problem çözme içinde ele alındığında, bu araştırmayı destekler şekilde, üstbiliş ile problem çözme başarısı arasındaki olumlu ilişki birçok araştırmada (Chan ve Mansoor, 2007; Cornoldi, 1997; Erdoğan, 2013; Karakelle, 2012; Özsoy ve Ataman, 2009; Pehlivan, 2012) ortaya çıkmıştır. Gerek günlük yaşam becerileri gerekse de akademik başarı bakımından, öğrencilere üstbilişsel bilgi ve becerilerin kazandırılması önemlidir (Yabaş ve Altun, 2009). TIMSS ve PISA gibi uluslararası sınavlarda Türk öğrencilerin matematikte gerçekleştirdikleri akıl yürütmelerini ifade edebilenlerin oranı \%1'dir. Bu sonuç, öğrencilerin ne öğrendiği kadar, neden ve niçin öğrendiklerini kavramaları; bilinçli bir şekilde öğrenmelerinin, dolayısıyla üstbiliş becerilerinin kavratılmasının önemini vurgulamaktadır.

Tüm bu sonuçlar birlikte yorumlandığında, problem genişletme etkinliklerinin öğrencilerin problem çözme başarısı ve üstbilişsel bilgi ve becerileri üzerinde artış sağladığı görülmüştür. Bu araştırmada elde edilen bulgulara göre, kontrol grubu üzerinde aynı etkiden söz edilememektedir. Matematikte yeni bir kavram olarak ele alınabilecek olan problem genişletmenin, araştırmanın problemine cevap olarak, problem çözme ve üstbiliş üzerinde etkili olduğu görülmüştür.

Araştırmada elde edilen bu sonuçlara dayalı olarak şu önerilerde bulunulabilir:

- $\quad$ Problem genişletme etkinliklerinin, problem çözme başarısı ve üstbiliş üzerinde olumlu etkisi olmaktadır. Matematiksel problem çözme çalışmalarında bu yaklaşımın benimsenmesi, problem çözme becerilerinde ve üstbilişsel becerilerin gelişiminde önemli katkı sağlayabilir.

- İlkokul Matematik Dersi Öğretim Programı'nda (2015) problem genişletmeden bahsedilmiş ancak literatürde bu konuda detaylı çalıșmalara rastlanmamıștır. $\mathrm{Bu}$ konuda ayrıntılı akademik çalışmalara ve bu doğrultuda öğretim etkinliklerinin geliştirilmesine yönelik çalışmalara ihtiyaç vardır.

- $\quad \mathrm{Bu}$ araştırmanın etki büyüklükleri düşük seviyede gözlendiğinden daha büyük çalışma gruplarında da araştırmanın yinelenmesi önerilebilir.

- $\quad$ Problem genişletme etkinliklerinin nasıl düzenleneceği tartışılmalı, sistematiği oluşturulmalıdır.

Ayrıca bu araştırma sonuçlarının, bir dizi araştırmaya daha yol açabileceği söylenebilir. Bunlar;

- $\quad$ Problem genişletme etkinlikleri hangi sınıf düzeyindeki öğrenciler açısından daha etkilidir?

- $\quad$ Problem genişletme etkinlikleri düzenlenirken, uygulanan yöntem daha farklı ve faydalı hale getirilebilir mi?

- $\quad$ Problem genişletme etkinliklerinin öğrencilerin problem kurma becerileri üzerinde bir etkisi var mıdır?

- $\quad$ Üstbilişsel bilgi ve beceri öğretiminin problem genişletme soruları çözümü üzerinde bir etkisi var midır?

- $\quad$ Problem genişletmenin, eleştirel düşünme ve akıl yürütme üzerinde etkisi var mıdır?

Açıklamalar: $\mathrm{Bu}$ çalışma, Seyfi ALAN'ın, Gökhan ÖZSOY'un danışmanlığında, Ordu Üniversitesi Sosyal Bilimler Enstitüsü’nde tamamladığı "Problem Genişletme Etkinliklerinin Problem Çözme ve Üstbilişse Etkisi” başl1klı tezinden üretilmiştir.

$\mathrm{Bu}$ araştırma, Ordu Üniversitesi Bilimsel Araştırma Projeleri Koordinasyon Birimi tarafından desteklenmiştir. Proje No: TP-1601 


\section{Kaynaklar}

Akay, H. (2006). Problem kurma yaklaşımı ile yapılan matematik öğretiminin öğrencilerin akademik başarısı, problem çözme becerisi ve yaratıcıllğg üzerindeki etkisinin incelenmesi. Doktora Tezi. Gazi Üniversitesi, Eğitim Bilimleri Enstitüsü, Ankara.

Akın, A., Abacı, R., ve Çetin, B. (2007). Bilişötesi farkindalik envanteri’nin Türkçe formunun geçerlik ve güvenirlik çalışması. Kuram ve Uygulamada Ĕ̈itim Bilimleri, 7(2), 655-680.

Ausubel, D.P. (1968). Educational psychology: A cognitive view. New York: Holt, Rinehart ve Winston.

Baki, A. ve Bell, A. (1997). Ortaögretim matematik öğretimi. Ankara: YÖK Dünya Bankası.

Baykul, Y. (2000). İlköğretimde matematik öğretimi: 1-5. Sinıflar için. Ankara: Pegem A. Yayıncılık.

Bingölbali, E., Özmantar, M. ve Alacaci, C. (2009). İlköğretimde karşılaşılan zorluklar ve çözüm önerileri. Ankara: Pegem A Yayıncılık.

Bruning, R., Schraw, G. ve Norby, M. (2014). Bilişsel psikoloji ve ögrretim. (Çev. ZN Ersözlü ve R. Ülker). Ankara: Nobel Akademik Yayıncılık.

Canbulat, T. (2016). Beyin uyumlu öğrenme yaklaşiminin ilköğretim beşinci sinif sosyal bilgiler dersinde öğrencilerin yönetici işlevlerine etkisi. International Journal of Active Learning, l(1), 29-48.

Chan, C. M. E. and Mansoor, N. (2007). Metacognitive behaviours of primary 6 students in mathematical problem solving in a problem-based learning setting. Paper Presented at the Redesigning Pedagogy, Culture, Knowledge and Understanding: Centre for Pedagogy and Practice Conference. National Institute of Education, Singapore.

Chudler E. H., Kuwana E. Y., Murray M. A. and Bleeker L. J. (2000). Neuroscience for kids: On-line and off-line activities for K-12 students and teachers. Soc. Neurosci. Abstr, 26, 41-56.

Cohen, J. (1988). Statistical power analysis for the behavioral sciences (2nd ed.). Hillsdale, NJ: Erlbaum.

Contreras, J. (2007). Unraveling the mystery of the origin of mathematical problems: using a problemposing framework with prospective mathematics teachers. Mathematics Educator, 17(2), 1523.

Cornoldi, D. L. C. (1997). Mathematics and metacognition: What is the nature of the relationship? Mathematical Cognition, 3(2), 121-139.

Çakıcı, D., Alver, B., ve Ada, Ş. (2006). Anlamlı öğrenmenin öğretimde uygulanmasi. Atatürk Üniversitesi Kazım Karabekir Eğitim Fakültesi Dergisi, 13, 71-80.

Demirel, Ö. (2010). Öğretme sanatı ögretim ilke ve yöntemleri. Ankara: Pegem A Yayıncılık.

Desoete A. ve Özsoy, G. (2009). Metacognition, more than the lognes monster?. International Electronic Journal of Elementary Education, 2(1), 1-6.

Diamond, M. C. (1988). Enriching heredity. New York: The Free Press.

Duman, B. (2007). Neden beyin temelli ögrenme. Ankara: Pegem Yayınevi. 
Erdoğan, F. (2013). Matematik öğretiminde üstbilişsel stratejilerle desteklenen işbirlikli öğrenme yönteminin, 6. sınıf öğrencilerinin akademik başarilarina, üstbilişsel becerilerine ve matematik tutumuna etkisinin incelenmesi. Doktora Tezi. Marmara Üniversitesi, İstanbul.

Erdoğan, F. ve Şengül, S. (2017). Matematik dersinde üstbilişsel stratejilerle desteklenen işbirlikli öğrenme yönteminin öğrencilerin üstbilişsel becerilerine etkisi. Eğitim ve Bilim, 42(192), 263301.

Flavell, J. H. (1979). Metacognition and cognitive monitoring: A new area of cognitivedevelopmental inquiry. American Psychologist, 34(10), 906-917.

Hacker, D. J. ve Dunlosky, J. (2003). Not all metacognition is created equal. New Directions for Teaching and Learning, 95, 73-79.

Haylock, D.Ö ve Cockburn, A. (2014). Küçük çocuklar için matematiği anlama. Ankara: Nobel Yayınları.

Karabey, B. (2017). TEOG'da matematikten tam puan alırsak matematik yapmış olur muyuz? Popular Sience Türkiye Dergisi, 57.

Karakelle, S. (2012). Üstbilişsel farkındalık, zekâ, problem çözme algısı ve düşünme ihtiyacı arasındaki bağlantılar. Ĕgitim ve Bilim, 37(164), 237-250.

Karataş, İ. (2008). Problem çözmeye dayalı öğrenme ortamının bilişsel ve duyuşsal öğrenmeye etkisi. Doktora Tezi. Karadeniz Teknik Üniversitesi, Eğitim Bilimleri Enstitüsü, Trabzon.

King, A. (1991). Effects of training in strategic questioning on children's problem-solving performance. Journal of Educational Psychology, 83(3), 307-320.

Larkin, S. (2010). Metacognition in young children. New York, NY: Routledge.

Lester, F, K. (1983). Trends and issues in mathematical problem-solving research. In R. Lesh and M. Landau (Eds.), Acquisition of mathematics concepts and processes (pp. 229-261). Orlando, FL: Academic Press.

Luchins, A. S. (1942). Mechanization in problem solving: The effect of Einstellung. Psychological Monographs, 54(6), i-95.

Mamona-Downs, J. (1993). On analyzing problem posing. Paper presented at the Proceedings of the 17th International Conference for the Psychology of Mathematics Education.

MEB. (2015). İlkokul Matematik Dersi (1, 2, 3 ve 4. Sinıflar) Öğretim Programı. Ankara: MEB.

Morin, E. (2003). Geleceğin eğitimi için gerekli yedi bilgi. Çeviren: H. Dilli. İstanbul: İstanbul Bilgi Üniversitesi Yayınları.

NCTM (2000). Principles and standards for school mathematics (Vol. 1). National Council of Teachers of Mathematics.

NMAP, N. M. A. P. (2008). Foundations for success: The final report of the National Mathematics Advisory Panel. US Department of Education.

Özsoy, G. ve Ataman, A. (2009). The effect of metacognitive strategy training on problem solving achievement. International Electronic Journal of Elementary Education, 1(2), 67-82. 
Özsoy, G. (2005). Problem çözme becerisi ile matematik başarısı arasındaki ilişki. Gazi Üniversitesi Gazi Eğitim Fakültesi Dergisi, 25(3), 179-190.

Özsoy, S. ve Özsoy, G. (2013). Eğitim araştırmalarında etki büyüklüğü raporlanması. İlköğretim Online, 12(2), 334-346.

Pehlivan, F. (2012). İlköğretim beşinci sınıf matematik dersinde üstbiliş stratejileri kullanımının ögrencilerin başarı ve tutumlarına etkisi. Yüksek Lisans Tezi. Niğde Üniversitesi, Niğde.

Phye, G. D. (2001). Problem-solving instruction and problem-solving transfer: The correspondence issue. Journal of Educational Psychology, 93(3), 571-590.

Piaget, J. (1976). Piaget's theory Piaget and his school (pp. 11-23): Springer.

Polat, M., Gönen, E., Parlak, B., Yıldırım, A. ve Özgürlük B. (2016). TIMSS 2015 Ulusal Matematik ve Fen Bilimleri Ön Raporu 4. ve 8. Sinıflar. Millî Eğitim Bakanlığı Ölçme, Değerlendirme ve Sinav Hizmetleri Genel Müdürlüğü.

Polya, G. (1988). How to solve it. New Jersey, NJ: Princeton University Pres.

Polya, G. (1981). Mathematical discovery: On understanding, learning, and teaching problem solving. Princeton, NJ: Princeton University Press.

Schoenfeld, A. H. (1992). Learning to think mathematically: Problem solving, metacognition, and sense making in mathematics. Handbook of research on mathematics teaching and learning. (pp. 334-370).

Schoenfeld, A. H. (1985). Mathematical problem solving. San Diego, CA: Academic Press.

Schunk, D. H. (2009). Öğrenme teorileri. Ankara: Nobel Yayın Dağıtım.

Smith, E. E. ve Kosslyn, S. M. (2014). Bilişsel psikoloji zihin ve beyin (Vol. 10). (Çev. Muzafer Sahin). Ankara: Nobel Yayınları.

Taş, U. E., Arıcı, Ö., Ozarkan, H. B. ve Özgürlük, B. (2016). PISA 2015 Ulusal Ön Raporu. Retrieved from: http://odsgm.meb.gov.tr/test/analizler/docs/PISA/PISA2015_Ulusal_Rapor.pdf

Temur, Ö. D. ve Kılınç, S. (2016). Okul öncesi ve sınıf öğretmenlerinin matematik öğretimi ve öğrenimi hakkındaki inanışları. International Periodical for the Languages, Literature and History of Turkish or Turkic, 11(3), 2557-2570.

Tertemiz, N. ve Çakmak, M. (2003). Problem çözme. Ankara: Gündüz Eğitim ve Yayıncılık.

Turhan, B. (2011). Problem kurma yaklaşımı ile gerçekleştirilen matematik öğretiminin ilköğretim 6. sınıf ögrencilerinin problem çözme başarıları, problem kurma becerileri ve matematiğe yönelik görüşlerine etkisinin incelenmesi. Yüksek Lisans Tezi. Anadolu Üniversitesi, Eğitim Bilimleri Enstitüsü, Eskișehir.

Van de Walle, J., Karp, K. S., Lovin, L. A. H. and Bay-Williams, J. M. (2010). Teaching student-centered mathematics: developmentally appropriate instruction for grades 3-5 (2nd ed.) Boston, MA: Pearson. 
Yabaş, D. ve Altun, S. (2009). Farklılaştırılmış öğretim tasarımının öğrencilerin özyeterlik algıları, bilişüstü becerileri ve akademik başarılarına etkisinin incelenmesi. Hacettepe Üniversitesi Eğitim Fakültesi Dergisi, 37(37), 201-214.

Yazgan, Y. ve Bintaş, J. (2005). İlköğretim dördüncü ve beşinci sınıf öğrencilerinin problem çözme stratejilerini kullanabilme düzeyleri: Bir öğretim deneyi. Hacettepe Üniversitesi Eğitim Fakültesi Dergisi, 28(28), 210-218. 


\section{Extended Abstract}

\section{Problem Statement}

The main objective of this research is to try to develop approaches to problem solving and higher thinking skills. After a problem has been solved and checked, it is thought that it would be much more useful to expand the currently solved problem rather than a new problem. These activities aiming at extending the problem will enable the transfer of experience, which is one of the most important factors in the problem-solving, to the strategy accumulation and the transfer of this accumulation to the following situations. It can be predicted that this method will contribute significantly to problem solving and high-level cognitive skills. Although problem extending is not considered as a separate concept with this title in the literature and it is not defined in detail; in problem extending activities, different questions can be added to the problem and problem solving by adding different questions to the problem which is solved systematically and without any change to a new problem after the problem is solved.

In this study, it is envisaged that problem extending activities can improve students' metacognitive skills, which means that they are aware of their own cognitive processes. However, it is anticipated that the students will have the ability to think and discover new ways. However, in some researches, it is observed that there are different forms of problem solving and setting up, such as changing the problem and extending the problem. It is thought that the research will bring a different dimension to problem solving, contribute to it and especially give a new perspective to the control stage defined as the last stage of the problem-solving process of Polya.

\section{Method}

The research was carried out on 61 students in a primary school in the central district of Rize province in the second half of the 2015-2016 school year and in the experimental group 30 students in 31 control groups. The equivalence of the groups to each other was examined with the ProblemSolving Achievement Test (KR-20=.87) developed by the researchers and an experimental and a control group were formed accordingly. In the selected experimental group, problem solving activities have been made with problem extending studies. The experimental group consisted of 31 students, $48 \%$ female and $52 \%$ male. In the control group, there are 30 students, $57 \%$ female and $43 \%$ male.

Metacognitive Knowledge and Skills Inventory was used to measure the metacognition level of the students. During the application process, a 40-minute preparation lesson were conducted for the students in the experimental group to comprehend the problem extending. The application lasted 9 weeks (19 lessons) with information and introduction.

\section{Findings and Discussions}

When the post-test averages were examined, the experimental group was $M=12.26$ ( $s d=3.82$ ) and the control group was $M=11.20(s d=3.62)$. It was observed that the average scores increased after the experiment in favour of the experimental group. Cohen's $d$ value was found to be 0.284 in this problem. This situation is seen as moderate in terms of effect size. The effect size value is close to the small effect size value and it can be thought that the sample of the study is at the limit level.

Metacognitive Knowledge and Skills Inventory pre-test means were $M=65.42(s d=13.50)$ in the experimental group and $M=72.67$ ( $s d=10.80)$ in the control group. In these results, it was observed that the control group had higher mean scores in the pre-test scores. In the end-test mean, the experimental group was $M=78.06(s d=15.54)$ and the control group was $M=79.30(s d=8.36)$. When the mean scores were examined, it was seen that the pre-test and post-test scores increased in both groups. The increase in the experimental group was 12.65 points and 6.63 in the control group. In order to examine the significance of the differences between the means, the difference between the pre-test post-test averages was found statistically significant in the experimental $(t=7.87, p<.01)$ and 
control $(t=3.74, p<.01)$ groups. According to the results, the effect size Cohen's $d$ value is seen as 0.09. This situation is seen in favour of both small and control groups in terms of effect size. The effect size value of this case is less than 0.20 and the negative value of this value is also negative effect of the problem expansion on metacognition. This may be because the sample is quite small.

\section{Conclusions and Recommendations}

As a result, it can be said that problem extending activities cause a significant increase in favour of the experimental group in terms of problem-solving achievement. However, this increase has a low effect size. In the case of working with a wider working group, the situation can be observed in a healthier manner.

After the problem is solved, many researchers have suggested working on the problem with different questions. However, when the literature is examined, it is observed that there are no comprehensive studies on the effect of studies to extend the problem. In the implementation phase of this study, it was observed that the problem extension was more effective on the students above the grade level. On the other hand, during the applications, it was observed that the weak students who had difficulty in solving or not solving the main problem were able to transfer the existing strategy to the extended problem after the solution of the main problem and the solution strategy. It can be thought that the difference between pre-test and post-test in the experimental group is due to this reason.

On the other hand, at the end of the research, it was observed that the problem expansion activities applied had an effect on the development of metacognitive knowledge and skills. The problem expansion activities aim to enable the students to look at the problem from different angles, to question the problem fiction and to think about the different possibilities. The questions posed to the students during these activities are the triggers of high-level thinking skills. In this regard, it is expected that the activities implemented will improve the metacognitive skills. 